\title{
Chemical limnology of a hypertrophic gravel-pit lake
}

\author{
M. Alvarez Cobelas ${ }^{1}$ \\ A. Rubiol \\ J.L. Velasco ${ }^{2}$
}

Keywords : Gravel-pit lake, chemistry, hypertrophy, Spain.

Some features of the chemical limnology of a hypertrophic, gravel-pit lake close to Madrid (Spain) have been studied at weekly intervals throughout a year. El Porcal Lake in an alkaline, slightly saline, water body without surface inflow or outflow. Anoxia is a common feature below the $2 \mathrm{~m}$ level from May to September. Dissolved oxygen oversaturation and $\mathrm{pH}$ above 9.00 occurred frequently in surface waters throughout the study period. Alkalinity totalled to 2.5-3.5 meq. $\mathrm{I}^{-1}$, bicarbonate being the main inorganic carbon fraction. Inorganic carbon is a key parameter in the chemistry of the lake, as indicated by statistical correlations. Nitrate and nitrite values were very high, probably as a result of high nitrification rates. Ammonia levels were lower than those of nitrite and nitrate. Soluble Reactive Phosphorus ranged over three orders of magnitude, sometimes occurring below detection limits. No plankton collapses have been observed but frequent oscillations in the chemical parameters have been the rule during the whole year. Groundwater seepage might be a very important source of nutrients. Most of the chemical features showed time lags of a week in autocorrelation functions, suggesting an unknown control mechanism for the temporal dynamics of the chemical limnology of El Porcal Lake.

Limnologie chimique d'un lac de gravière hypereutrophe.

Mots clés : Lac de gravière, chimie, hypereutrophie, Espagne.

Quelques caractéristiques chimiques d'un lac de gravière hypereutrophe proche de Madrid (Espagne) ont été étudiées de manière hebdomadaire durant une année. Le lac El Porcal est un plan d'eau alcalin, légèrement salin, sans entrée ni sortie d'eau de surface. L'anoxie se produit communément sous $-2 \mathrm{~m}$ de profondeur de mai à septembre. La sursaturation en oxygène dissous et des pH supérieurs à 9,00 sont apparus fréquemment au cours de l'étude. L'alcalinité s'élève à 2,5-3,5 meq. $\mathrm{l}^{-1}$, le bicarbonate étant la principale fraction carbonée minérale. Le carbone minéral est le paramètre-clé de la chimie du lac, comme le montrent les corrélations statistiques. Les teneurs en nitrate et nitrite sont très élevées, probablement en raison d'une nitrification active. Les valeurs de l'ammoniaque sont plus basses que celles des nitrites et nitrates. Les teneurs en phosphore réactif soluble s'étalent sur trois puissances de dix d'amplitude, tombant quelquefois en dessous des limites de détection. Aucun effondrement planctonique n'a été observé, mais de fréquentes oscillations dans les paramètres chimiques ont été la règle tout au long de l'année. Les apports par la nappe sont peut-être une source importante de nutriments. Beaucoup de caractères chimiques montrent des pas de temps de une semaine dans les fonctions d'autocorrélation, ce qui suggère un mécanisme de contrôle inconnu de la dynamique temporelle de la limnologie chimique du lac El Porcal.

\section{Introduction}

Lake eutrophication has been one of the main topics in the limnology of the last two decades, mostly as a result of Vollenweider's (1968) account.

1. Centro de investigaciones del agua (CSIC), La Poveda, Arganda del Rey, E-28500 Madrid, Espagne.

2. Museo nacional de ciencias naturales (CSIC), Jose Gutierrez Abascal 2, E-28006 Madrid, Espagne.
When nutrient loads are exceedingly high, the lake is overfertilized and a severe eutrophication occurs. This is termed as hypertrophy. There are several features characterizing the hypertrophy of a given lake, namely, mass growth of a few dominant species, suppression of plankton periodicity, lack of inorganic nutrient depletion in the vegetation period, high oxygen oversaturation at day and night, relatively low content of dissolved organic matter, high 
bioturbidity and high dissolved oxygen production (Lentvaar 1979). Unfortunately a great number of hypertrophic ecosystems do exist in the World but their limnology has been scarcely studied and few remedial actions have been suggested (Ripl 1983, Shapiro 1980). A decade later from the workshop that Barica \& Mur (1980) edited our knowledge on hypertrophic lakes is still scanty and no recent account covering this area of research has appeared. Even reports on hypertrophic lakes are so scattered within the limnological literature that it is too difficult to acquire an updated idea of this fascinating limnological field.

Gravel-pit lakes are ecosystems that can be heavily polluted if they lay on the watershed of polluted rivers. They are filled with surface waters when an inlet coming from the nearby river exists but most of the times water is supplied by groundwater seepage. Moreover, the limnology of lakes without surface drainage is still poorly understood and even the contribution of seepage to the limnological features is almost unknown (Brock et al. 1982). To our knowledge, the only grave!-pit lakes that have been studied so far are those of the Seine basin (Cardinal 1983, Garnier 1982, 1989, Garnier \& LescherMoutoué 1984, Garnier et al. 1987, Moreau 1982, Vermorel 1985), those of the Garonne basin (Labroue \& Pinnay 1986, Labroue et al. 1988 , Laville \& Lafond-Grellety 1969), and others in the Rhine (Banoub 1978, 1980, Backhaus \& Banoub 1988) and the Thames valleys (Abdel Karim 1967).

As a result of increasing building in Madrid (Spain) in the last 30 years, many gravel-pit lakes have appeared in the watersheds of the rivers surrounding the city since river banks are a cheap source for both sand and gravel. Most of these lakes lay wery close to watercourses subjected to heavy organic and industrial pollution and this is the reason why they have become hypertrophic. During 1984 and 1985 we have undertaken a research program on the limnology of one of these gravel-pit lakes and some features of its chemical limnology are to be reported here.

El Porcal kake is located on the Jarama river watershed, $20 \mathrm{~km}$ SE Madrid and $20 \mathrm{~m}$ from the river course. It lacks surface inlet or outlet. Mineral exploitation is currently being undertaken and has been performed throughout the sampling period. Its morphometric and gross chemical features are reported by Alvarez Cobelas et al. (1987). No plankton collapses have been recorded in the period under study.

\section{Material and methods}

Sampling was carried out weekly (aprox.) by means of a peristaltic pump from May 1984 to June 1985 at a $6 \mathrm{~m}$ deep station. Water was pumped up at 9 a.m. from one meter equidistant depths in the water column. "In situ » dissolved oxygen was measured with a YSI-57 probe at $0.25 \mathrm{~m}$ depths. $\mathrm{Ph}$ and conductivity were measured on pumped water with CRISON electrodes. On most sampling dates, dissolved oxygen and $\mathrm{pH}$ were measured again at noon in surface waters in order to survey some indicators of primary production. Within half an hour collected water was analized for total solids, bicarbonate, carbonate, carbon dioxide, ammonia, nitrite, nitrate and SRP (Soluble Reactive Phosphorus), following both APHA (1985) and Rodier (1984) procedures. Nutrient analyses were carried out after a preliminary filtration of water samples through $0,45 \mu \mathrm{m}$ Millipore filters. On a bimonthly basis calcium content was also measured by the EDTA method of titration (APHA 1985).

A sampling site in the nearby Jarama river $(20 \mathrm{~m}$ apart from the lake) was monthly surveyed and the same analyses were carried out. No samples in the groundwater seepage were taken.

Areal hypolimnetic oxygen deficits (AHOD) were calculated as shown by Hutchinson (1938). A calcite saturation index calculation was carried out following APHA's (1985) method. Finally, both the balance and oscillations of total inorganic nutrients (C, N and $\mathrm{P}$ ) were estimated on an annual basis using Barica's (1974: p. 348) method; the $\mathrm{N}-\mathrm{NH}_{3}$ temporal kinetics was also added in order to give an index of particulate organic matter breakdown.

Statistics were performed on average data for the water column. The high frequency of thermal destratifications during the stagnant periods (unpublished results) gives support to this criterion. The statistics performed on the data have been correlated, auto- and cross-correlations, these latter to survey temporal periodicities. Data have been log transformed when necessary to meet statistical criteria for the tests involved. Data for autocorrelations have been detrended by differencing whereas data for 
cross-correlations have been detrended by means of ARIMA models. BMDP routines (Dixon et al. 1983) have been used throughout.

\section{Results}

Table 1 shows average values ( \pm SD) and ranges of the chemical parameters in E1 Porcal Lake and in the nearby Jarama river. On the whole, the most conspicuous feature is the high variability (as standard deviation) of any parameter in the lake as well as in the river. The wide ranges involved can be ascertained from Figs. 1-8.

The time course of conductivity depicts maximal values during most of the mixing period (Fig. 1). As a rule, bottom layers have higher conductivities.

Table 1 : Average values \pm Standard Deviation of chemical parameters measured in El Porcal Lake and jarama river from May 1984 to June 1985.

\begin{tabular}{|c|c|c|}
\hline & El Porcal Lake & Jarama river \\
\hline Conductivity $\left(\mu \mathrm{s} . \mathrm{cm}^{-1}\right)$ & $1316 \pm 74$ & $849 \pm 167$ \\
\hline $\mathrm{pH}$ & $8.27 \pm 0.45$ & $7.44 \pm 0.53$ \\
\hline Total solids (mg.1 ${ }^{-1}$ ) & $952 \pm 67$ & $641 \pm 122$ \\
\hline Dissolved oxygen (mg. $\mathrm{l}^{-1}$ ) & $8.02 \pm 3.80$ & $5.23 \pm 3.40$ \\
\hline $\mathrm{CO}_{2}$ (mg.1-1) & $1.46 \pm 4.14$ & $6.76 \pm 11.40$ \\
\hline $\mathrm{CO}_{3} \mathrm{H}^{-}\left(\mathrm{mg} \cdot \mathrm{I}^{-\mathrm{I}}\right)$ & $156.0 \pm 38.5$ & $178 \pm 32$ \\
\hline $\mathrm{CO}_{3}=\left(\mathrm{mg} . \mathrm{l}^{-1}\right)$ & $14.1 \pm 27.8$ & $<0.5$ \\
\hline $\mathrm{NH}_{4}^{+}$(mg. $1^{-1}$ ) & $0.85 \pm 0.62$ & $6.78+5.83$ \\
\hline $\mathrm{NO}_{2}^{-}$(mg.1 $\left.1^{\mathrm{l}}\right)$ & $1.55 \pm 2.54$ & $0.66 \pm 0.95$ \\
\hline $\mathrm{NO}_{3}^{-}$(mg.l $\left.{ }^{-1}\right)$ & $9.35 \pm 5.99$ & $6.93 \pm 4.39$ \\
\hline $\operatorname{SRP}\left(m g . l^{-1}\right.$ ) & $1.00 \pm 0.73$ & $4.80 \pm 6.91$ \\
\hline
\end{tabular}

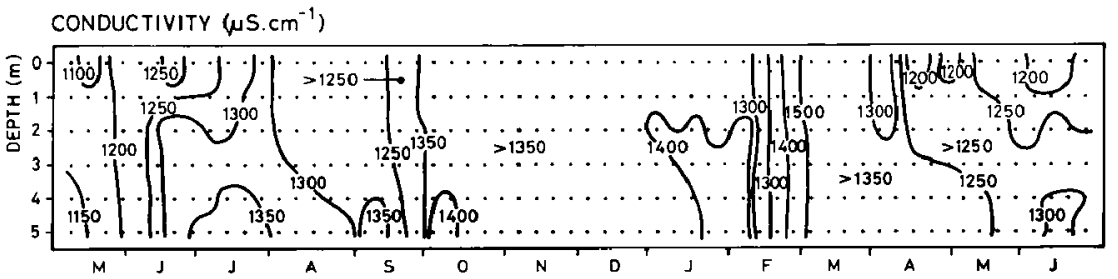

Fig. 1. : Depth-time isopleths of conductivity in El Porcal Lake from May 1984 to June 1985.

$\mathrm{pH}$ in surface waters is much higher during the stratification periods. In the isothermal period $\mathrm{pH}$ is homogeneous in the water column (Fig. 2). pH above 10 is sometines reached in surface waters in the stagnation periods even at earlier hours in the morning. However, when surface $\mathrm{pH}$ at noon is compared with that of the earlier time of sampling no statistically significant difference is obtained ( $\mathrm{t}$ test). No values below neutrality have been measured either in surface or bottom waters.
Total solids are higher in the bottom layers (Fig. 3). This could be a side effect to mineral exploitation of the lake since the suspended silt accumulates near the bottom. On an annual basis, total solids content is lower in the period May-December 1984 , and higher afterwards, perhaps reflecting an increasing effort in mineral exploitation. Log-log correlations between conductivity and total solids have been tried with the following results. Firstly, in surface waters both are statistically significantly related $(r=0.57, p<0.05)$. Secondly, in bottom waters 
there is no statistically significant correlation between both parameters at such a probability level ( $\mathrm{r}$ $=0.04 \mathrm{p}<0.05$ ). These results suggest the importance of non-ionic chemical fractions in bottom waters as compared with those of surface waters.

Oversaturation of dissolved oxygen in surface waters is a common feature throughout the stagnation periods and partly in the mixing period ( Fig. 4). However, anoxia is commonly found below the $2 \mathrm{~m}$ layer in both stratification periods (Fig. 5).
Thermal Autumn overturn occur on the earlier days of September. Surface dissolved oxygen levels rapidly fall below $2 \mathrm{mg} . \mathrm{I}^{-1}$ and take three weeks to recover stratification levels. However, there has been a short episode of oxygen depletion in late October but by mid November high levels of oxygen have been recorded again. In mid-December there is another episode of oxygen depletion in the whole water column, which is again rapidly followed by saturation values in the next weeks ( $F i g$. 4).

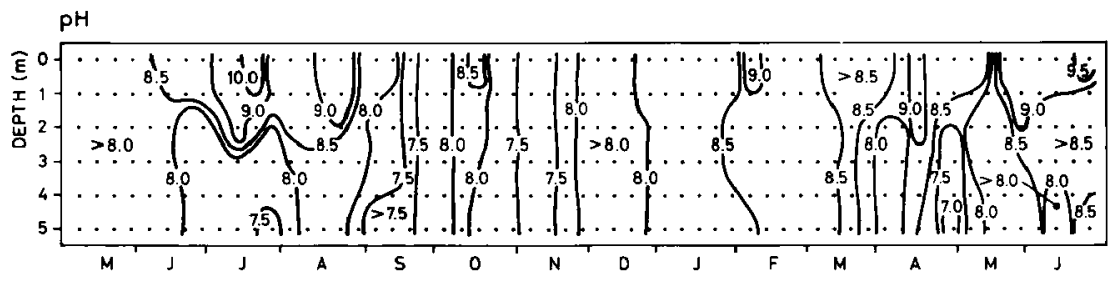

Fig. 2 : Depth-time isopleths of pH in El Porcal Lake from May 1984 to June 1985.

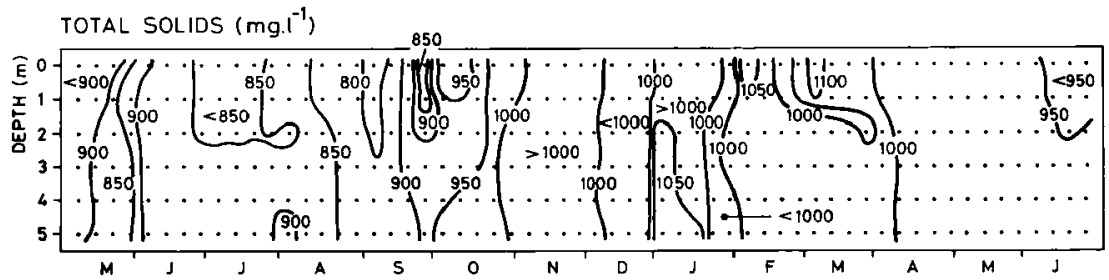

Fig. 3 : Depth-time isopleths of total solids in El Porcal Lake from May 1984 to June 1985.

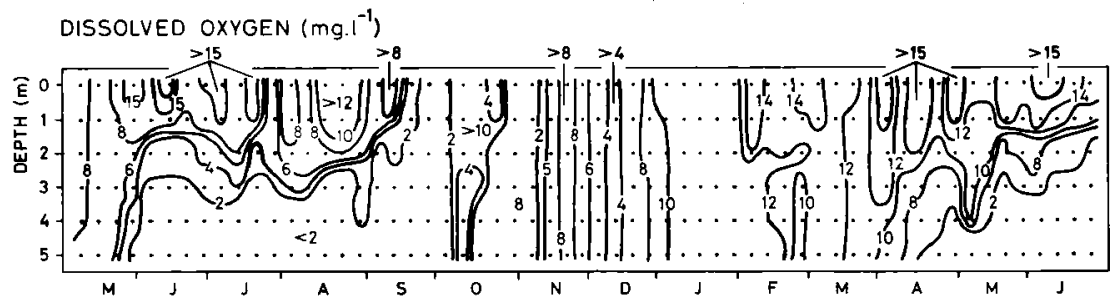

Fig. 4 : Depth-time isopleths of dissolved oxygen in El Porcal Lake from May 1984 to June 1985. 


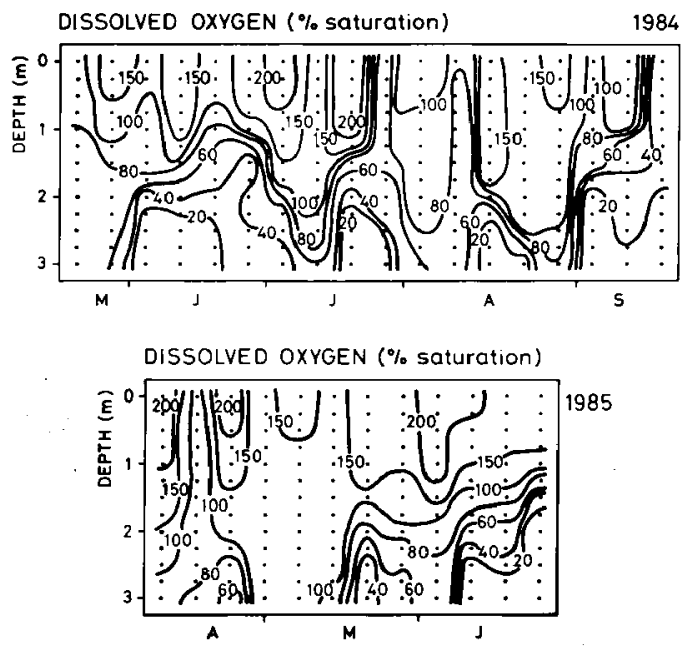

Fig. 5 : Depth-time isopleths in the photic layer of dissolved oxygen in El Porcal Lake during 1984 stratification and the first part of 1985 stratification.

From February onwards oxygen oversaturation in surface waters is the rule. The most conspicuous feature in the dissolved oxygen temporal dynamics is the rapidly changing concentrations in the water column, arising from high primary production, frequent thermal overturns and biomass mineralization.

A Wilcoxon test for comparison of photic oxygen contents on a surface basis between those of early hours and those of the noon hours is statistically significant ( $p<0.0001$ ), indicating higher oxygen contents at noon, probably resulting from phytoplankton photosynthesis. AHOD values amount to $0.60 \mathrm{~g} . \mathrm{m}^{-2} . \mathrm{d}^{-1}$ and $1.55 \mathrm{~g} . \mathrm{m} .^{-2} \cdot \mathrm{d}^{-1}$ for the 1984 and 1985 stagnation periods, respectively. Concerning inorganic carbon, carbon dioxide content is only conspicuous during the Autumn overturn (Fig. 6A), reflecting a decrease in $\mathrm{pH}$ in such a period (see Fig. 2). Bicarbonate depicts an inverse relationship with depth during stratification periods (Fig. 6B), probably as a result of phyto- plankton uptake in surface waters which shifts inorganic carbon equilibrium towards carbonate. Bicarbonate content is higher in the mixing period. Alkalinity amounts to $2.5-3.5 \mathrm{meq} \cdot \mathrm{1}^{-1}$. Carbonate content is lower in the mixing period in the whole water column and in bottom layers during the stagnation periods (Fig. 6C), which is a consequence of pH distribution. The calcite saturation index in surface waters reflects oversaturation $(1.67 \pm 1.12)$ whereas in bottom waters it shows resolution values $(0.88 \pm$ $0.50)$. The number of values of such index is scarce but they appear to be homogeneous in the water column in the mixing period and much higher in the surface layer in the stratification periods. It is likely that calcite precipitation occurs in surface waters in the latter since values above 2 are commonly observed.

Ammonia time course shows maximal values during the mixing period. Ammonia content in the water column is often high in bottom layers (Fig. 7A), probably as a result of organic matter 


\section{$\mathrm{A}=\mathrm{CO}_{2} ; \mathrm{B}=\mathrm{CO}_{3} \mathrm{H} ; \mathrm{C}=\mathrm{CO}_{3}=\left(\mathrm{mg} . \mathrm{l}^{-1}\right)$}
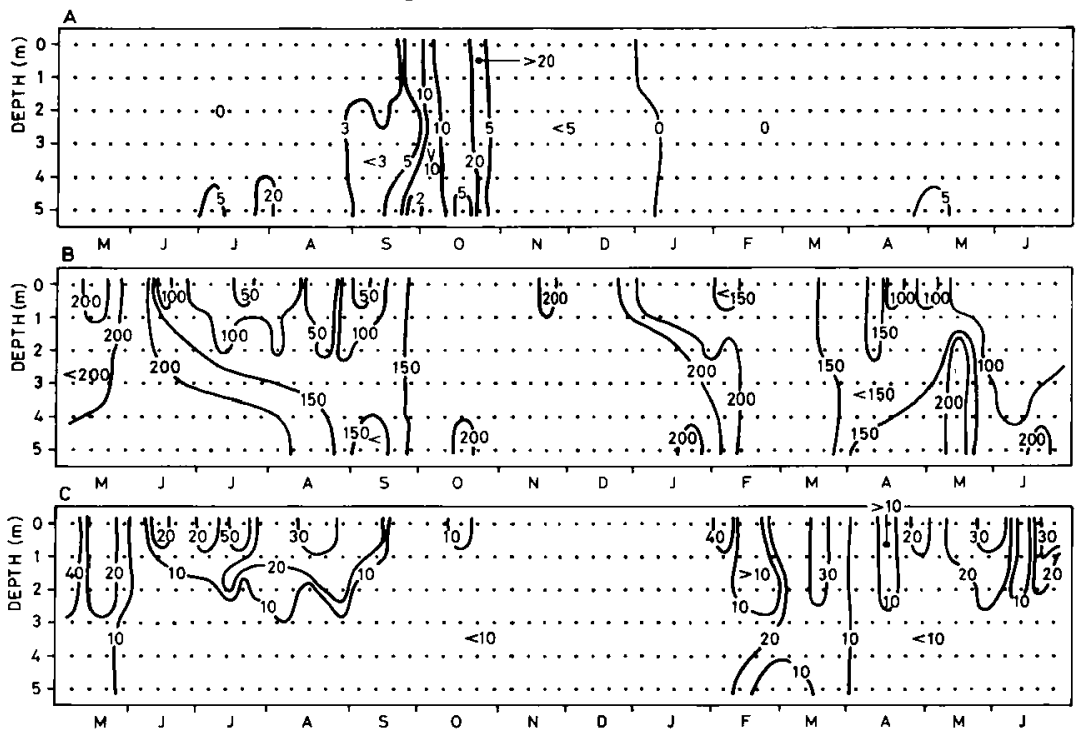

Fig. 6 : Depth-time isopleths of inorganic carbon in El Porcal Lake from May 1984 to June 1985. A: $\mathrm{CO}_{2} ; \mathrm{B}: \mathrm{CO}_{3}$ $\mathrm{H}^{-} ; \mathrm{C}: \mathrm{CO}_{3}=$. All units in $\mathrm{mg} . \mathrm{I}^{-1}$.

mineralization and laking of nitrification due to anoxia. Ammonia depletion is common in surface waters. Another interesting feature is the highly variable ammonia content in the water column (see the period of November in Fig. 7A), suggesting rapid interconversion in the inorganic nitrogen pool. Nitrite concentrations show very high values many times in the period under study, probably resulting from high nitrification activities in the water column (Fig. 7B). Its maxima occur in May-June 1984 but also in December-March 1985. Average values (Table 1) are unexpectedly high. In the stagnation periods nitrite concentration increases in oxygenated waters (i.e., those of photic layers). Nitrite content also changes very rapidly since a week period is enough to increase or decrease it by an order of magnitude.
Nitrate shows minimal values at the Autumn overturn (Fig. 7C). During the remainder of the year cycle nitrate concentrations are fairly high and vertical inhomogeneities are rare. Dramatic fluctuations in the nitrate content usually occur within a week period (see October in Fig. 7C).

SRP is often recorded below detection levels (Fig. 8 ), mostly in surface waters in the stagnation periods. Its maximal values, which can also be very high, take place during the mixing period, its range spanning three orders of magnitude.

Areal inorganic carbon (the sum of carbon dioxide plus bicarbonate plus carbonate) display a clear seasonal pattern as well as areal SRP, increasing in the mixing period and diminishing in the stagnant periods (Fig. 9). 


$$
\mathrm{A}=\mathrm{NH}_{4}^{\circ} ; \mathrm{B}=\mathrm{NO}_{2}^{-} ; \mathrm{C}=\mathrm{NO}_{3}^{-}\left(\mathrm{mg} . \mathrm{l}^{-1}\right)
$$
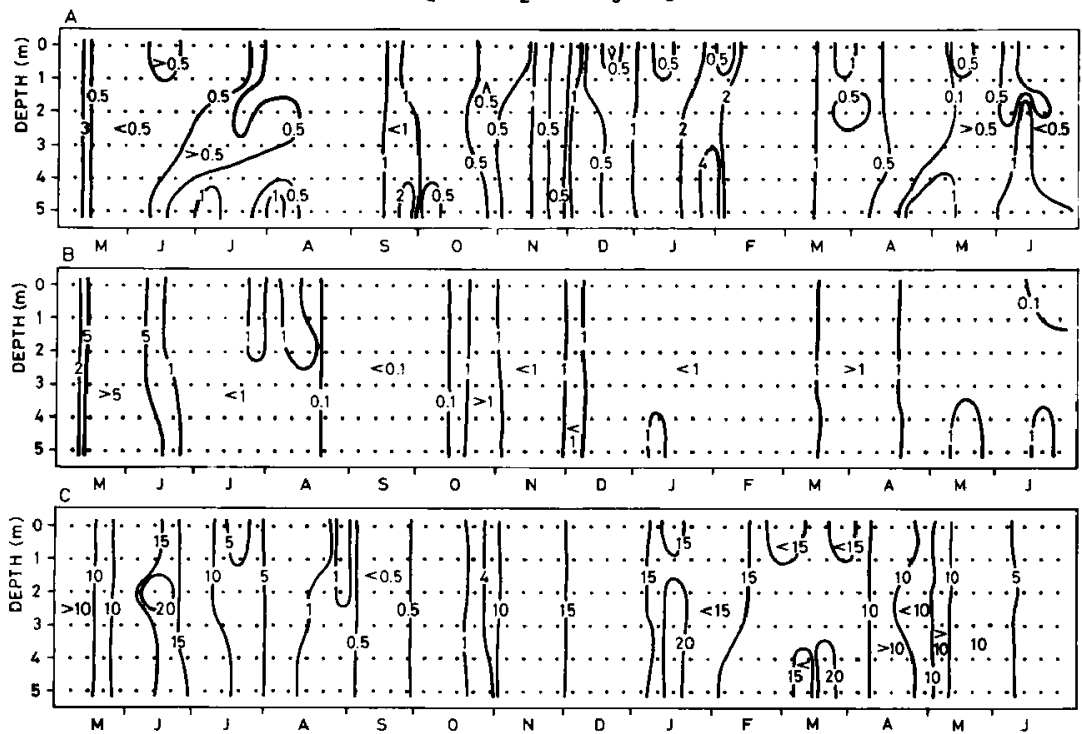

Fig. 7 : Depth-time isopleths of inorganic nitrogen in El Porcal Lake from May 1984 to June 1985. A : $\mathrm{NH}_{4}{ }^{+}$; $\mathrm{B}$ : $\mathrm{NO}_{2}{ }^{-} ; \mathrm{NO}_{3}{ }^{-}$. All units in mg.1 $1^{-1}$.

SOLUBLE REACTIVE PHOSPHORUS (mg..$^{-1}$ )

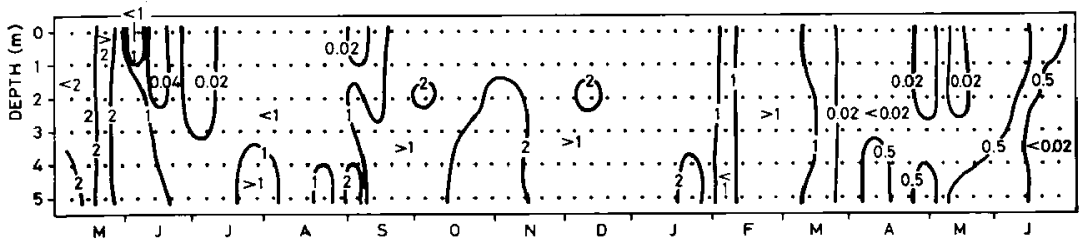

Fig. 8 : Depth-time isopleths of Soluble Reactive Phosphorus in El Porcal Lake from May 1984 to June 1985. 


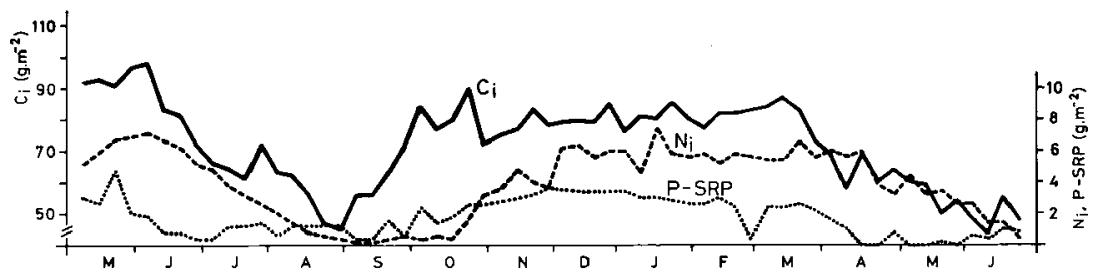

Fig.9 : Areal inorganic carbon $\left(\mathrm{C}_{\mathrm{i}}\right)$, nitrogen $\left(\mathrm{N}_{\mathrm{i}}\right)$ and phosphorus (P-SRP) in El Porcal Lake from May 1984 to June 1984.

Areal P-SRP appears to be lower in the 1985 stratification rather than in the 1984 stratification. Areal inorganic nitrogen is not always higher than areal P-SRP and its year cycle is not so clear-cut remarkable as those of inorganic carbon and phosphorus
(Fig. 9), since maximal values are attained both in stratification and mixing periods.

Temporal oscillations of inorganic nutrients are shown in Fig. 10. Carbon, nitrogen and P-SRP oscillate very much during the whole period under study.
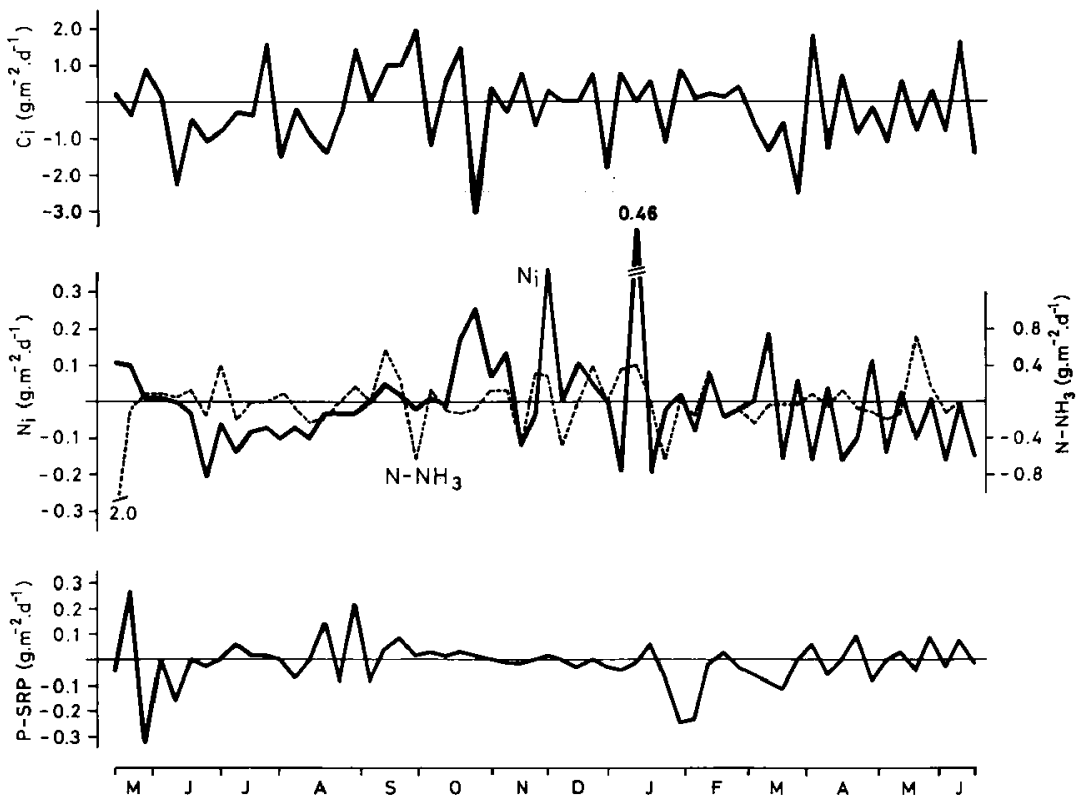

Fig. 10 : Nutrient gains (positive values) or losses (negative values) daily rates in El Porcal Lake from May 1984 to June 1985 , according to the method by Barica (1974). Symbols as in Fig. 9. 
Ammonia oscillations also occur. These results suggest high rates of seepage input, uptake, recycling and regeneration of nutrients in El Porcal Lake since time periods of a week are enough to deplete or regain nutrient levels in the water column.

Nutrient balances for the period May 1984-April 1985 reveal a dramatic decrease in inorganic carbon and P-SRP whereas inorganic nitrogen slightly increases (Table 2). Ammonia also diminishes albeit slightly. Taking into account systematic errors in sampling and analyses around $5 \%$ as Barica (1974) does, ammonia cannot be considered to vary significantly and inorganic nitrogen only shows minor increases. These results suggest the importance of groundwater seepage in supplying nutrients since the sediments as a single source of nutrients are unlikely to supply the differences in demand shown in Table 2 (aprox. $30 \%$ in carbon and $42 \%$ in phosphorus).

Statistical correlations between chemical parameters averaged for the whole water column reveal a variety of statistically significant relationships at $\mathrm{p}$ $<0.05$ (Table 3). Nevertheless, most of the correlation coefficients are not high. On the whole, inor- ganic carbon appears to be correlated with most of the remainder chemical parameters, which is not an unexpected result since the temporal dynamics of the three inorganic carbon forms cover the whole spectrum of temporal dynamics of the other chemical parameters. Dissolved oxygen shows a positive relationship with nitrate and a negative one with SRP, suggesting the acknowledged linkage between nitrification and high levels of dissolved oxygen and an inverse covariation with SRP, respectively. Finally, detrended autocorrelations have been tried for all the chemical parameters, resulting in statistically significant autocorrelations in the time domain of week (Table 4). Some parameters show significant time lags of two weeks (i.e., total solids, dissolved oxygen, bicarbonate, carbonate, nitrate, SRP, etc.) and there are even statistically significant longer time lags for some parameters (Table 4), such as dissolved oxygen with monthly periodicities and inorganic nutrients on a areal basis with a 21 days' periodicity. Very interestingly, no statistically significant relationships emerge when chemical parameters have been cross-correlated.

Table 2: Sum of positive ( $\Sigma \mathrm{dM}+)$ and negative $(\Sigma \mathrm{dM}-)$ areal changes of nutrients and their differences (Diff. D) for one year-cycle (May 1984-April 1985) in El Porcal Lake. Units are g.m. ${ }^{-2} \cdot \mathrm{y}^{-1}$. C : inorganic carbon ; $\mathrm{N}$ : inorganic nitrogen; $\mathrm{N}^{-\mathrm{NH}_{3}}$ : ammonia nitrogen ; P-SRP : Soluble Reactive Phosphorus.

\begin{tabular}{lcccc}
\hline & $\mathrm{C}$ & $\mathrm{N}$ & $\mathrm{N}-\mathrm{NH}_{3}$ & $\mathrm{P}-\mathrm{SRP}$ \\
\cline { 3 - 5 }$\Sigma \mathrm{dM}+$ & 17.9 & 2.35 & 5.75 & 1.15 \\
$\Sigma \mathrm{dM}-$ & 25.5 & $\mathbf{2 . 1 5}$ & 6.06 & 1.97 \\
Diff. D & -7.6 & $\mathbf{0 . 2 0}$ & -0.31 & -0.82 \\
\% & -29.8 & +8.5 & -5.1 & -41.7 \\
\hline
\end{tabular}

Table 3 : Correlation coefficients matrix among chemical features of El Porcal Lake. Values have been averaged for the water column prior to correlation tests. All parameters but $\mathrm{pH}$ have been subjected to log-transformations to meet statistical criteria. COND : conductivity ; TS : Total Solids ; ${ }^{*}:$ statistically significantly correlation at $p<0.05$.

\begin{tabular}{|c|c|c|c|c|c|c|c|c|c|c|c|}
\hline & COND & $\mathrm{PH}$ & TS & $\mathrm{O}_{2}$ & $\mathrm{CO}_{2}$ & $\mathrm{CO}_{3} \mathrm{H}^{--}$ & $\mathrm{CO}_{3}=$ & $\mathrm{NH}_{4}^{+}$ & $\mathrm{NO}_{2}{ }^{-}$ & $\mathrm{NO}_{3}^{-}$ & SRP \\
\hline COND & 1.00 & & & & & & & & & & \\
\hline PH & $0.49^{*}$ & 1.00 & & & & & & & & & \\
\hline TS & -0.19 & -0.09 & 1.00 & & & & & & & & \\
\hline $\mathrm{O}_{2}$ & -0.00 & $0.60^{\circ}$ & 0.23 & 1.00 & & & & & & & \\
\hline $\mathrm{CO}_{2}$ & $0.33^{*}$ & $-0.66^{*}$ & 0.07 & $-0.68^{\circ}$ & 1.00 & & & & & & \\
\hline $\mathrm{CO}_{3} \mathrm{H}^{-}$ & $-0.34^{*}$ & $-0.39^{*}$ & $0.37^{*}$ & -0.07 & 0.24 & 1.00 & & & & & \\
\hline $\mathrm{CO}_{3}=$ & $-0.53^{*}$ & $0.60^{*}$ & $-0.37^{*}$ & $0.48^{\circ}$ & $-0.64^{*}$ & $-0.49^{\circ}$ & 1.00 & & & & \\
\hline $\mathrm{NH}_{4}^{+}$ & 0.19 & 0.01 & $0.46^{*}$ & 0.20 & -0.04 & $0.32^{*}$ & -0.07 & 1.00 & & & \\
\hline $\mathrm{NO}_{2}^{-}$ & $-0.33^{*}$ & 0.09 & -0.11 & 0.08 & -0.06 & $0.34^{*}$ & 0.07 & -0.18 & 1.00 & & \\
\hline $\mathrm{NO}_{3}^{-}$ & 0.18 & 0.14 & $0.48^{*}$ & $0.48^{*}$ & $-0.33^{*}$ & $0.46^{*}$ & -0.07 & 0.20 & 0.28 & 1.00 & \\
\hline SRP & $0.30^{*}$ & $-0.47^{*}$ & 0.19 & $-0.35^{*}$ & $0.43^{*}$ & $0.67^{*}$ & $-0.57^{*}$ & 0.24 & 0.03 & 0,02 & 1.00 \\
\hline
\end{tabular}




\section{Discussion}

Out of the seven criteria for hypertrophy that Lentvaar (1979) suggests, this study gives support to two for El Porcal lake, namely, high dissolved oxygen oversaturation at day and night since we have often measured oxygen oversaturation early in the morning (Fig. 5), and high potential dissolved oxygen production throughout the year (Fig. 4). There is a third criterion that is not met (i.e., no depletion of any nutrient in the vegetation period) since SRP is depleted below detection limits in the early 1985 stratification (Fig. 8) but providing the high frequency of thermal destratifications in El Porcal Lake, this phenomenon of SRP depletion only might be operating at short time scales. Two other criteria have been also demonstrated by unpublished results, i.e., high bioturbidity (as shown by high chlorophyll « a » content) and suppression of plankton periodicity. Hence El Porcal Lake may be termed as hypertrophic.

There is a great variety of gravel-pits as trophic state is concerned (Banoub 1980, Garnier et al. 1987, Laville \& Lafond-Grellety 1969). El Porcal Lake is perhaps one of those of acute hypertrophy (sensu Lentvaar 1979), only comparable with the Bassin Intermediaire of the Vaudreuil basin in the Seine River (Moreau 1982). An interesting feature of $\mathbf{E l}$ Porcal Lake is the high nitrification rates resulting in high nitrite contents in most times of the year (Fig. 6B) except during Autumn overturn. To our knowledge, this high nitrite content is one of the highest ever recorded in any lake (Brezonik 1972), only Olah (1980) reports similar nitrite concentrations occurring in Hungarian fishponds. The reason for such enhancement of nitrite contents is far from clear, perhaps an inhibition on nitrifying bacteria growth by high pH (Sharma \& Ahlert 1977). But nitrification inhibition is by no means a well known event of the nitrification process (Sharma \& Ahlert 1977). This nitrification phenomenon may be enhanced by dissolved oxygen oversaturation (Sharma \& Ahlert 1977 ) in surface waters (Figs. 4-5). The ammonia source for such nitrification process is likely to be the nearby Jarama river, having average ammonia concentrations of $6.78 \mathrm{mg} . \mathrm{l}^{-1}$ (Table 1), which could enter the lake via groundwater movement. Ammonia volatilization as a result of elevated $\mathrm{pH}$ should be included as another way of diminishing ammonia content to be added to nitrification. Such a process has been also reported for Canadian hypertrophic lakes by Murphy \& Brownle (1981) and is likely to occur in El Porcal Lake where $\mathrm{pH}$ above 9.00 is a common feature.

AHOD values in El Porcal Lake are higher in 1985 than in 1984 but they are in the range of other hypertrophic lakes (Effler et al. 1986).

In the nutrient balance model of hypertrophic lakes (Barica 1974) no groundwater seepage infiltration is assumed. This is clearly not the case for El Porcal Lake where supply by seepage might be the main way to meet nutrient demands for the lake metabolism. In fact what our results suggest (Table 2 ) is an unbalanced metabolism with shortages in carbon and phosphorus. It is very likely that, given the high $\mathrm{pH}$ involved, a significant fraction of inorganic carbon is lost to the sediments by calcite precipitation which in turn coprecipitates SRP (Otsuki \& Wetzel 1972). On the other hand, calcite oversaturation has been shown to occur in El Porcal Lake in the stratification periods, and another evidence in support of this is the steady decrease in areal inorganic carbon in such periods (Fig. 9).

The real value of Barica's method lies in the fact that intense oscillations in the nutrient content of the water column could be revealed (Fig. 10), these oscillations occurring in El Porcal Lake throughout the period under study. In other words, chemical oscillations are not restricted to certain year phases, as in the hypertrophic lakes studied by Barica (1974), but they occur irrespective of the vegetation period. The nature of these oscillations is far from clear since there are too many factors that can interact to cause them (i.e. surface runoff, uptake and release by organisms or sediments, biomass breakdown and mineralization, atmospheric inputs, groundwater migration, etc.). Anyway, rapid oscillations of chemical features such as those shown for El Porcal Lake are common in hypertrophic ecosystems (Uhlmann 1980), and we have observed them irrespective of plankton collapses. Concerning statistical correlations between chemical parameters, it is not surprising that statistically significantly relationships are not as high as expected since chemical features greatly depend upon factors other than those studied (Heaney et al. 1986 : underwater light field, buoyancy gradients, uptake and release by organisms, chemical complexation, particulate dynamics, etc.). The resulting correlations are but ones of the variety of potential relationships occurring 
in El Porcal Lake. Most of them cannot be easily explained and if so, we will not be sure whether we are dealing with covariabilities or causal relationships. To the former one can assign the high correlation coefficient obtained between SRP and bicarbonate, to the latter the relationships between inorganic carbon and $\mathrm{pH}$ (Table 3 ) are to be assigned. This uncertainty in causal relationships might be partly due to the poor temporal resolution of the sampling program. Chemical processes in El Porcal Lake must occur at time scales much shorter than a week as shown by the rapid fluctuations in both most of the parameters studięd (Figs. 4-8) and weekly areal nutrient differences (Fig. 10). So the great number of autocorrelation lags of a week (Table 4) have no clear limnological meaning, except that of a control factor of chemical features operating at time scales of a week. The nature of this factor remains unknown for the time being. The reason why for the lack of statistically significantly cross-correlations also remains elusive. The only thing that seerns to be sure is that sampling programs in the chemical environment of hypertrophic lakes should be developed with higher temporal resolution (Uhlmann 1980). Such shorter time scales have been realized by Harris (1987) in his temporal studies in the mesotrophic lake Ontario. Anyway, it appears that inorganic carbon is one of the key variables in the chemistry of El Porcal Lake since it is by far the feature having the greatest number of statistically significant correlations with other chemical parameters.

Table 4 : Autocorrelation of the chemical features of El Forcal Lake for the whole period under study. All time series have been detrended by differencing prior to autocorrelation tests. Only statistically significantly autocorrelations ( $\mathrm{p}<0.05$ ) have been included. $\mathbf{L}$ : time lag (weeks), $\mathrm{R}$ : correlation coefficient.

\begin{tabular}{|c|c|c|}
\hline & $\mathrm{L}$ & $\mathbf{R}$ \\
\hline Conductivity & 1 & 0.57 \\
\hline $\mathrm{pH}$ & 1 & 0.32 \\
\hline \multirow[t]{2}{*}{ Total solids } & 1 & 0.41 \\
\hline & 2 & 0.44 \\
\hline \multirow{4}{*}{ Dissolved oxygen } & 1 & 0.63 \\
\hline & 2 & 0.34 \\
\hline & 4 & 0.42 \\
\hline & 5 & Q0.45 \\
\hline $\mathrm{CO}_{2}$ & 3 & 0.32 \\
\hline \multirow{2}{*}{$\mathrm{CO}_{3} \mathrm{H}^{-}$} & 1 & 0.80 \\
\hline & 2 & 0.63 \\
\hline $\mathrm{CO}_{3}=$ & $\frac{1}{2}$ & 0,63 \\
\hline \multirow{3}{*}{ Areal inorganic carbon } & 1 & ass \\
\hline & 2 & 0.78 \\
\hline & 3 & 061 \\
\hline $\mathrm{NH}_{4}{ }^{+}$ & 1 & 944 \\
\hline \multirow{2}{*}{$\mathrm{NO}_{2}^{-}$} & 1 & Qs4 \\
\hline & 3 & 0,33 \\
\hline \multirow[t]{3}{*}{$\mathrm{NO}_{3}^{-}$} & 1 & 0.73 \\
\hline & 2 & 0.65 \\
\hline & 3 & 0.53 \\
\hline \multirow{4}{*}{ Areal inorganic nitrogen } & I & 0.98 \\
\hline & 2 & 0.66 \\
\hline & 3 & 0.75 \\
\hline & 0.63 & \\
\hline \multirow[t]{2}{*}{ SRP } & 1 & 0.61 \\
\hline & 2 & 0.43 \\
\hline \multirow[t]{3}{*}{ Areal SRP } & 1 & 0.69 \\
\hline & 2 & 0.59 \\
\hline & 3 & 0.52 \\
\hline
\end{tabular}




\section{Acknowledgements}

The widely scattered literature on gravel-pit lakes is another drawback for their study. Fortunately, we have received a great deal of reports, theses, reprints and encouragement from Prof. François Lelong (Orleans), $D^{x}$ Michel Meybeck (Paris) and $D^{r}$ Josette Garnier (Paris). We are very grateful to all of them. An anony mous reviewer has provided very useful suggestions. Teresa Madruga kindly typed the manuscript. Fernando Delgado drew the figures.

\section{References}

Abdel Karim (A.G.). 1967. - Algal flora of certain gravel pits in the Thames Valley, U.K. Hydrobiologia, $30: 577.599$.

Alvarez Cobelas (M.), Rubio (A.), Araúzo (M.), Alarcón (P.) \& Alario (V.). 1987. - Morfometria y composición quimica de una laguna de gravera. Limnetica, $3: 91-95$.

APHA. 1985. - Standard Methods for the Examination of Waters and Wastewaters. I6th ed. Washington DC. 1268 p.

Banoub (M.W.). 1978. - Limnological observations on a recently dredged pond (gravel-pit). Verh. Internat. Verein. Limnol., 20 : $1844-1849$.

Banoub (M.W.). 1980. - Nitrate overdose : effects and consequences. In J. Barica \& L. Mur (Eds.) : Hypertrophic Ecosystems : 133-137. De W. Junk Publ. The Hague.

Backhaus (D.) \& Banoub (M.W.). 1988. - Development of a phytoplankton community in a recently dredged gravel-pit pond in West Germany. Verh. Internal. Verein. Limnol., 23 : 1522-1529.

Barica (J.). 1974. - Some observations on internal recycling, regeneration and oscillation of dissolved nitrogen and phosphorus in shallow self-contained lakes. Arch. Hydrobiol., $73:$ 334-360.

Barica (J.) \& Mur (L.), eds. 1980. - Hypertrophic Ecosystems. D W. Junk Publ. The Hague. 348 p.

Brezonik (P.). 1972. - Nitrogen : sources and transfomations in natural waters. In H.E. Allen \& J.R. Kramer (Eds) : Nutrients in Natural Waters: 1-50. J. Wiley \& Sons. NY.

Brock (T.D.), Lee (D.R.), Janes (D.) \& Winek (D.). 1982. Groundwater seepage as a nutrient source to a drainage lake ; Lake Mendota, Wisconsin. Water Res., 16 : 1255-1263.

Cardinal (C.). 1983. - Composition et évolution saisonnière du phytoplancton du lac de Crèteil (Val-de-Marne, France). Revue fr. Sci. Eou, $2: 153-172$.

Dixon (W.J.), Brown (M.B.), Engelman (L.), Frane (J.W.), Hill (M.A.), Jenrich (R.I.) \& Toporek (J.D.). 1983. - BMDP Statistical Sofnware. 1983 Printing with Additions. Univ. California Press. Berkeley. 734 p.

Effler (S.W.), Perkins (M.G.) \& Brooks (C.). 1986. - The oxygen resources of the hypolimnion of ionically enriched Onondaga Lake, NY, U.S.A. Water, Air and Soil Pollut., $29: 93-108$.

Garnier (1.). 1982. - Praduction primaire d'une sablière lac de Créleil). Etude de certains facteurs de contrôle. Thèse Jeme Cycle. Univ. Paris VI. 121 p.

Garnier (J.). 1989. - Peuplements phytoplanctoniques et bacteries heterotrophes d'un lac pet profond (lac de Créteil, Région Parisienne). Production, fonctionnement, evolution. Thèse Doctorat. Univ. Paris VI. 331 p.

Garnier (J.), Lelong (J.F.) \& Meybeck (M.). 1987. - Comparaison physico-chimique er biologique de sept bassins artificiels dans les alluvions de la Région parisienne. Naturaliste can. (Rev. Ecol. Syst.), $114: 325-342$.
Garmier (J.) \& Lescher-Moutoué (F.). Successions saisonnières phytozooplanctoniques dans un écosystème lacustre peu profond (tac de Créteil, France). Verh. Internat. Verein. Limnol., 22 : $99-1002$.

Harris (G.P.). 1987. - Time series analysis of water quality data from Lake Ontario : implications for the measurement of water quality in large and small lakes. Freshwoter Biology, $18: 389-403$.

Heaney (S.I.), Smyly (W.J.P.) \& Talling (J.F.). 1986. Interactions of physical, chemical and biological processes in depth and time within a productive English lake during Summer stratification. Int. Revue ges. Hydrobiol., $71: 441-494$.

Hutchinson (G.E.), 1938. - On the relation berween the oxygen deficit and the productivity and tipology of lakes. Int. Revue ges. Hydrobiol., $36:$ 336-355.

Labroue (J.) \& Pinnay (G.). 1986. - Epuration naturele des nitrates des eaux souterraines : possibilités d'application au réaménaggement des lacs de gravières. Annis, Limnol, 22 : 83-88.

Labroue (J.), Toureng (J.N.), Mieussens (C.), Robert (J.) \& Donville (B.). 1988. - Rôle des lacs de gravières dans la diminution des teneurs en nitrates des aquifères alluviaux de la vallée de la Garonne. Essai de quantification. Annls. Limnol. 24 : 3) +38 .

Laville (A.) \& Lafond-Grellety (J.). 1969. - Le lac nord de Bordeaux. L'origine des eatux, l'évolution de la nappe d'eau du lac 1966-1969. Trib. Cebedeau, 307-308: 294-312.

Lentvaar (P.). 1979. - Zeven criteria voor hypertrofie. $\mathrm{H}_{2} \mathrm{O}, 12$ : $368-372,387$

Moreau (N.). 1982. - Etude biogéochimique comparative de différents plans d'eau de la plaine alluviale du Vaudreuil (Eure). Thèse Jème Cycle. Univ. Orléans. $138 \mathrm{p}$.

Murphy (T.P.) \& Brownlee (B.G.). 1981. - Ammonia volatilization in a hypertrophic prairie lake. Can. J. Fish. Aquat. Sci., 38 : $1035 \cdot 1039$.

Oláh (J.). 1980. - Structural and functional quantification in a series of Hungarian hypertrophic shallow lakes. In J. Barica \& L. Mur (eds.) : Hypertrophic Ecosystems : 191-202. W. Junk Publ. The Hague.

Ttsuki (A.) \& Wetzel (R.G.). 1972. - Coprecipitation of phosphates with carbonates in a marl lake. Limmol. Oceanogr., 17 : 763-767.

Ripl (W.). 1983. - Control of algal growth by mechanical and hydraulic methods. Waters Supply, $1: 237-243$.

Rodier (J.). 1984. - L'Analyse de l'Eau : Eaux naturelles, Eaux résiduaires, Eau de Mer. Ed. Bordas. Paris. 1365 p.

Shapiro (J.). 1980. - The importance of trophic-level interactions to the abundance and species composition of algae in lakes. In J. Barica \& L. Mur (eds.) : Hyperirophic Ecosystems : 105-116. Dr W. Junk Publ. The Hague.

Sharma (B.) \& Ahlert (R.C.). 1977. - Nitrification and nitrogen removal. Water Res. $11: 897-925$.

Uhlmann (D.). 1980. - Stability and multiple steady states of hypertrophic ecosystems. In J. Barica \& L. Mur (ads.) : Hypertrophic Ecosysterms : 235-247. D' W. Junk Publ. The Hague.

Vermorel (P.). 1985. - Contribution à la connaissance de la sédimentation dans plusieurs plans d'eau artificiels de la plaine alluviale du Val de Reuil (Eure). Thèse 3ème Cycle. Univ. Orléans. 215 p.

Vollenweider (R.A.). 1968. - Scientific Fundamentals of the Eutrophication of Lakes and flowing Waters with particular Reference to Nitrogen and Phosphorus as Factors in Eutrophication. OECD. Paris. 159 p. 